Diabetologia, Suppl. to 9, 351-355 (1973)

(C) by Springer-Verlag 1973

\title{
Glipizide versus Tolbutamide in Maturity-Onset Diabetes, an Open Comparative Study
}

\author{
K. Fuchs \\ Received: April 5, 1973, and in revised form: July 7, 1973, accepted: July 7, 1973
}

\begin{abstract}
Summary. The preliminary results of an open com. parative study of the oral antidiabetic glipizide and tolbutamide have shown that in all patients, except for 1 [2] of 16 glipizide cases and [2 [1] of 12 tolbutamide cases, an adequate control of the diabetes could be achiev.
\end{abstract}

Glipizide, a new and potent sulphonylurea derivative has been compared with tolbutamide in an open comparative study in terms of dosage, efficacy, toleration, incidence of primary and secondary failures and effect on the parameters of lipid metabolism.

Glipizide is a sulphonylcyclohexylurea with the following structural formula:

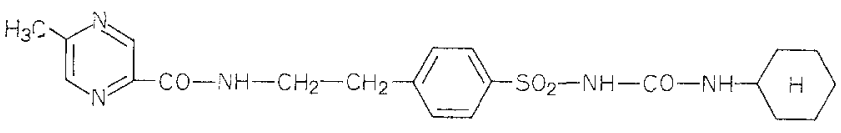

Fig. 1

The chemistry, pharmacokinetics, and clinical results obtained with glipizide have been described in a series of recent papers $[1,2,3,4,5,6,7,8,9,10,11]$.

\section{Method}

1. Prior to the onset of treatment with either trial drug both newly diagnosed cases and patients previously treated with oral antidiabetics were maintained on diet alone for a period of 3 to 7 days.

Diagnostic criteria:

- Fasting level of blood glucose over $120 \mathrm{mg} \%$

(Glucose-Oxydase-Perid Method)

- Postprandial values over $180 \mathrm{mg} \%$

- Glucosuria

(qualitative: strips B-M-Test Glucose

quantitative: polarimetry)

- Clinical symptoms of diabetes mellitus

Diet: $1500-2000$ cals/day according to situation of patient carbohydrates: $150-220 \mathrm{~g} / \mathrm{day}$ about $45 \%$ carbohydrates

about $35 \%$ fat

about $20 \%$ protein ed. There were no side effects besides clinical signs of hypoglycaemia in 4 patients on Glipizide.

Key words: Sulfonylureas, naturity-onset diabetes, glipizide, tolbutamide, hypoglycaemic sulphonamides, oral antidiabetic drugs, lipids.
2. The starting dose of glipizide was $2.5 \mathrm{mg}$ and $5 \mathrm{mg}$, respectively. Dosage adjustments were made every 3 to 7 days up to $20 \mathrm{mg} /$ die (maximum $30 \mathrm{mg}$ ).

The daily dosage was either given as a single dose or, if this appeared to be necessary, as multiple doses. The dosage range of Tolbutamide was $500 \mathrm{mg}$ to 4000 mg.

3. The following parameters were measured before treatment, weekly during the first month of treatment and then at monthly intervals: blood glucose levels (enzymatic) fasting and 1 and $2 \mathrm{~h}$ after a test meal (breakfast consisting of $27 \mathrm{~g} \mathrm{CHO}=113$ cals); $24 \mathrm{~h}$ urinary glucose excretion; blood pressure and pulse in lying and standing position; and body weight.

4. Total cholesterol, free cholesterol, non-esterified fatty acids, triglycerides, alkaline phosphatase, BUN, uric acid and the serum electrolytes $\mathrm{Na}^{+}$and $\mathrm{K}^{+}$were determined before treatment and then every 3 months.

Fundus examination and ECG were performed before treatment and will be repeated after 12 months therapy.

5. Criteria of Assessment: a) Clinical (Cl): Clinical assessment according to the overall picture based on the evaluation of all laboratory values as well as the patient's state in respect of feeling of well-being, ability to do his work, absence of more severe hypoglycaemic episodes and other data.

$1=$ excellent, $2=$ good, $3=$ fair, $4=$ poor, $5=$ negative

This assessment reflects the personal judgement of the author, taking into account the patients professional and private situation.

b) Chemical $1\left(\mathrm{Ch}_{1}\right)$ : according to blood glucose values during therapy.

The following limits were arbitrarily selected as reference values: 
This arbitrary selection is considered to be justified by the following points:

Table 1

\begin{tabular}{lllll}
\hline & fasting & $\begin{array}{l}1 \mathrm{~h} \text { after } \\
\text { loading }\end{array}$ & $\begin{array}{c}2 \mathrm{~h} \text { after } \\
\text { loading }\end{array}$ \\
\hline \multirow{2}{*}{ Range } & low & $<100$ & $<160$ & $<120$ \\
& medium & $100-130$ & $160-220$ & $120-150$ \\
& high & $>130$ & $>220$ & $>150$ \\
\hline
\end{tabular}

Only three ranges (low, medium, high) are defined by these values, thus simplifying evaluation and not overstressing minor differences.

Fasting and $2 \mathrm{~h}$ values are lower, $1 \mathrm{~h}$ values higher compared with criterion $\mathrm{Ch}_{2}$ (see below), thus rendering the selected ranges more appropriate to the blood glucose values actually observed.

These values selected for the evaluation of results coincide with the values recommended for the diagnosis of diabetes $[12,13]$. The evaluation is based on the position of the arithmetic means of the blood glucose concentrations in this reference system (fasting value and 1 and $2 \mathrm{~h}$ after loading). The mean values were calculated from the blood glucose concentrations measured. at the monthly assessment visits.

According to the distribution of these individual three mean values (fasting, $1 \mathrm{~h}, 2 \mathrm{~h}$ ) for each patient under therapy, assessment is accomplished in the following way:

Table 2

\begin{tabular}{ll}
\hline 1-excellent & $\begin{array}{l}\text { Distribution of mean blood glucose values } \\
\text { (monthly assessments): } \\
\text { three values in low range } \\
\text { or } \\
\text { two values in low range and } \\
\text { one value in medium range } \\
\text { three values in medium range } \\
\text { or } \\
\text { two values in medium range and } \\
\text { one value in low or high range }\end{array}$ \\
$3=$ fair & $\begin{array}{l}\text { one value in medium range and } \\
\text { two values in high range } \\
\text { three values in high range }\end{array}$ \\
\hline
\end{tabular}

\section{Assessment Scale}

c) Chemical $2\left(\mathrm{Ch}_{2}\right)$ : in terms of blood glucose values according to table:

The most unfavourable value was decisive for the evaluation according to $\mathrm{Ch}_{2}$.

6. Patient Selection: 40 patients with maturity -onset diabetes were allocated to one of the treatment groups (according to a randomization list) so that 20 patients were treated with glipizide and 20 patients with tolbutamide.
Patients were excluded for the following reasons:

- hypersensitivity to one of the trial drugs,

- ketoacidosis (plasma $\mathrm{HCO}_{3}^{-}$below $17 \mathrm{mEq} / \mathrm{l}$ ),

- juvenile and brittle diabetes,

- renal and/or hepatic insufficiency,

- pregnancy,

- patients treated with insulin in excess of $40 \mathrm{U}$ daily,

- severe complications such as gangrene, tuberculosis, etc.

\section{Preliminary Results}

\section{Patient Information}

Duration of diabetes: Average: 3.3 years (range 3 months to 11 years) glipizide-patients: 3.2 years (3 months to 10 years) tolbutamide-patients: 3.5 years (4 months to 11 years).

Previous antidiabetic treatment: All patients but one had been treated previously with different sulphonylureas, sometimes in combination with biguanides. Three of the glipizide-patients had previous insulin treatment ( $\leq 20 \mathrm{U} / \mathrm{day}$ ).

Body weight: Measured by the ratio

$$
\frac{\text { Weight }(\mathrm{kg})}{\text { Height }(\mathrm{cm})-100},
$$

half of the patients were $20 \%$ or more overweight ( 8 of 16 in glipizide-group and 6 of 12 in tolbutamide-group).

Average weight changes from initial pretreatment values to values at last assessment visit were minimal (glipizide $+0.4 \%$, range $-4.0 \%$ to $+5.5 \%$, tolbutamide $+0.7 \%$, range $-3.1 \%$ to $+7.3 \%$ of initial value) .

Glucosuria at monthly assessments:

Glipizide

Tolbutamide

$$
\begin{aligned}
& 41 \text { assessments none } \\
& 2 \text { assessments } 2 \mathrm{~g} / 24 \mathrm{~h} \\
& 1 \text { assessment } 4 \mathrm{~g} / 24 \mathrm{~h} \\
& 2 \text { assessments } 5 \mathrm{~g} / 24 \mathrm{~h} \\
& 2 \text { assessments } 6 \mathrm{~g} / 24 \mathrm{~h}
\end{aligned}
$$

33 assessments none
1 assessment $3 \mathrm{~g} / 24 \mathrm{~h}$
2 assessments $12 \mathrm{~g} / 24 \mathrm{~h}$

In the following the results obtained in 28 patients (16 glipizide, 12 tolbutamide) with a total of 84 monthly assessments (48 glipizide. 36 tolbutamide) are reported (see Tables $4,5,6$ ).

Summary of the assessments according to the criteria under point 5 .

The mean values of all patients (with standard error) prior to treatment and during therapy (mean values of monthly assessments) with the trial drugs glipizide and tolbutamide are shown in Fig. 2.

For ready orientation, the reference values $\left(\mathrm{Ch}_{1}\right.$. see method 5) are also shown in this figure. 
There were no side effects, besides clinical signs of hypoglycaemia in 4 patients on glipizide.

In patients No. 1, 5, 7, 15 a state with clinical signs of hypoglycaemia (tachycardia, increased perspiration, tremor) was observed approximately $5 \mathrm{~h}$ after lunch and about $9 \mathrm{~h}$ after intake of the daily dose of $2.5 \mathrm{mg}$ glipizide. Blood glucose values taken at this stage continued with diet alone. This patient is not included in Tables 4 and 6 .

In 3 patients $[5,7,20]$ the metabolic state improved under glipizide to such an extent that the patients could be transferred to diet alone after 3 months of treatment. Table 5 shows the values during |glipizide therapy only.

Table 3.

\begin{tabular}{llcl}
\hline $\begin{array}{l}\text { Therapeutic } \\
\text { results }\end{array}$ & \multicolumn{3}{l}{ Glycaemia (values in whole blood) } \\
\cline { 2 - 4 } & fasting & $1 \mathrm{~h} \mathrm{p.p.}$ & $\mathbf{2 \mathrm { h } \mathrm { p } . \mathrm { p } .}$ \\
\hline excellent & $\leq 110 \mathrm{mg} / 100 \mathrm{ml}$ & $\leq 150 \mathrm{mg} / 100 \mathrm{ml}$ & $\leq 130 \mathrm{mg} / 100 \mathrm{ml}$ \\
good & $\leq 130 \mathrm{mg} / 100 \mathrm{ml}$ & $\leq 180 \mathrm{mg} / 100 \mathrm{ml}$ & $\leq 150 \mathrm{mg} / 100 \mathrm{ml}$ \\
fair & $\leq 150 \mathrm{mg} / 100 \mathrm{ml}$ & $\leq 200 \mathrm{mg} / 100 \mathrm{ml}$ & $\leq 180 \mathrm{mg} / 100 \mathrm{ml}$ \\
poor & $\leq 20 \mathrm{mg} / 100 \mathrm{ml}$ & $\leq 280 \mathrm{mg} / 100 \mathrm{ml}$ & $\leq 250 \mathrm{mg} / \mathbf{1 0 0} \mathrm{ml}$ \\
negative & $>220 \mathrm{mg} / 100 \mathrm{ml}$ & $>280 \mathrm{mg} / 100 \mathrm{ml}$ & $>250 \mathrm{mg} / 100 \mathrm{ml}$ \\
\hline
\end{tabular}

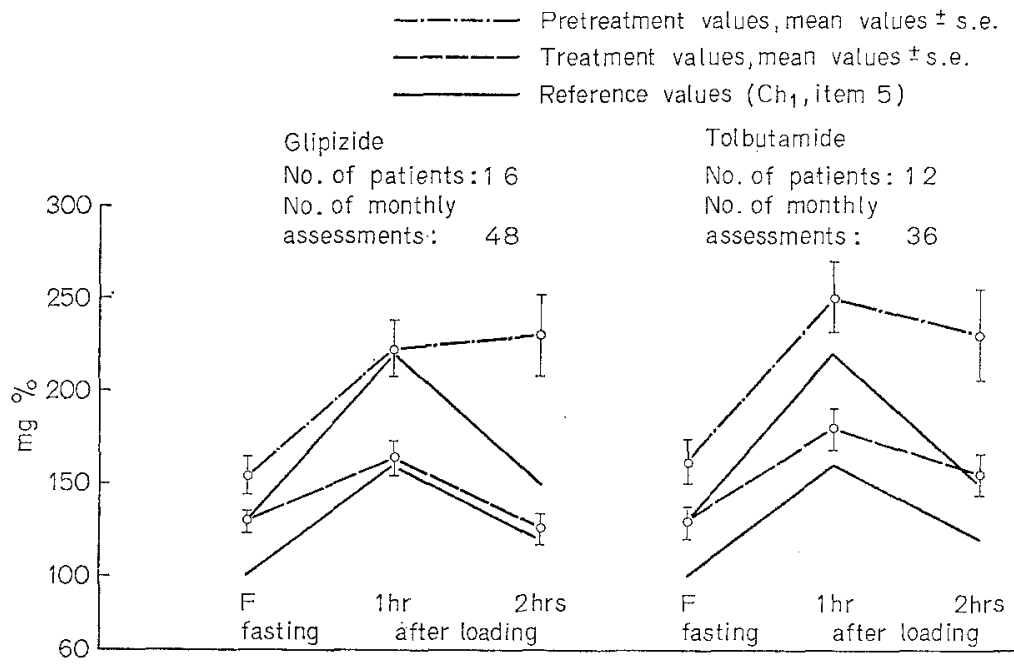

Fig. 2. .... pretreatment values, mean values \pm s.e. --- treatment values, mean values \pm s.e. - - reference values $\left(\mathrm{Ch}_{1}\right.$, point 5)

Table 4

\begin{tabular}{llllllll}
\hline & \multicolumn{3}{l}{ Glipizide } & & \multicolumn{3}{c}{ Tolbutamide } \\
\cline { 2 - 4 } \cline { 6 - 7 } & $\mathrm{Cl}$ & $\mathrm{Ch}_{1}$ & $\mathrm{Ch}_{2}$ & & $\mathrm{Cl}$ & $\mathrm{Ch}_{1}$ & $\mathrm{Ch}_{2}$ \\
\hline Excellent & 7 & 7 & 3 & 1 & 5 & 3 \\
Good & 4 & 6 & 7 & 7 & 3 & 2 \\
Fair & 4 & 1 & 3 & 0 & 2 & 3 \\
Poor & 0 & & 3 & 2 & & 3 \\
Negative & 1 & 2 & 0 & 2 & 2 & 1 \\
\hline
\end{tabular}

were not within the hypoglycaemic range (No. 1: 64 $\mathrm{mg} \%, 68 \mathrm{mg} \%$, No. 5: $63 \mathrm{mg} \%$, No. $7: 58 \mathrm{mg} \%$, No. 15: $79 \mathrm{mg} \%$ ). These manifestations appeared in patient No. 1 twice and in patients No. 5 and 7 once after 3 months of treatment. Patient No. 15 showed these symptoms after about 2 weeks of therapy. In all cases it was regarded as a typical relative hypoglycaemia $[14,15]$ and could be controlled by oral carbohydrate.

In 1 patient [26] tolbutamide was discontinued prior to the first monthly assessment and treatment

\section{Discussion}

Because of the small number of patients and the short period of observation, only preliminary results can be presented. Since the blood glucose values recorded at the assessment visits constitute an essential, though not the only, criterion of evaluation and as there exists no generally accepted reference standard for the "chemical" evaluation [16], the results were graded according to clinical criteria $(\mathrm{Cl})$ as well as two different "chemical" criteria $\left(\mathrm{Ch}_{1}, \mathrm{Ch}_{2}\right.$; see criteria of assessment, point 5 , and Tables $4,5,6$ ).

Taking into account that with the criterion $\mathrm{Ch}_{1}$ a four-grade scale, and with the criteria $\mathrm{Cl}$ and $\mathrm{Ch}_{2}$ a fivegrade scale is used for classification, the results can be considered as more or less concordant. Where this is not the case, as in patient No. 29 (Table 5), the more flexible clinical classification is better suited than the calculation of mean values of longer periods and the classification according to rigid evaluation patterns. 
In the case of patient No. 29 frequent assessments and inquiries have shown that this patient had reduced the dose on her own. After the patient had observed the dosage recommended, the quality of control could be rated as moderate from the clinical point of view. to the results of Emanueli et al. [9]. These authors stated that favourable control according to different criteria was possible in $76-83 \%$ of several hundred patients.

Considering the fact that the initial mean value one

Table 5. Glipizide

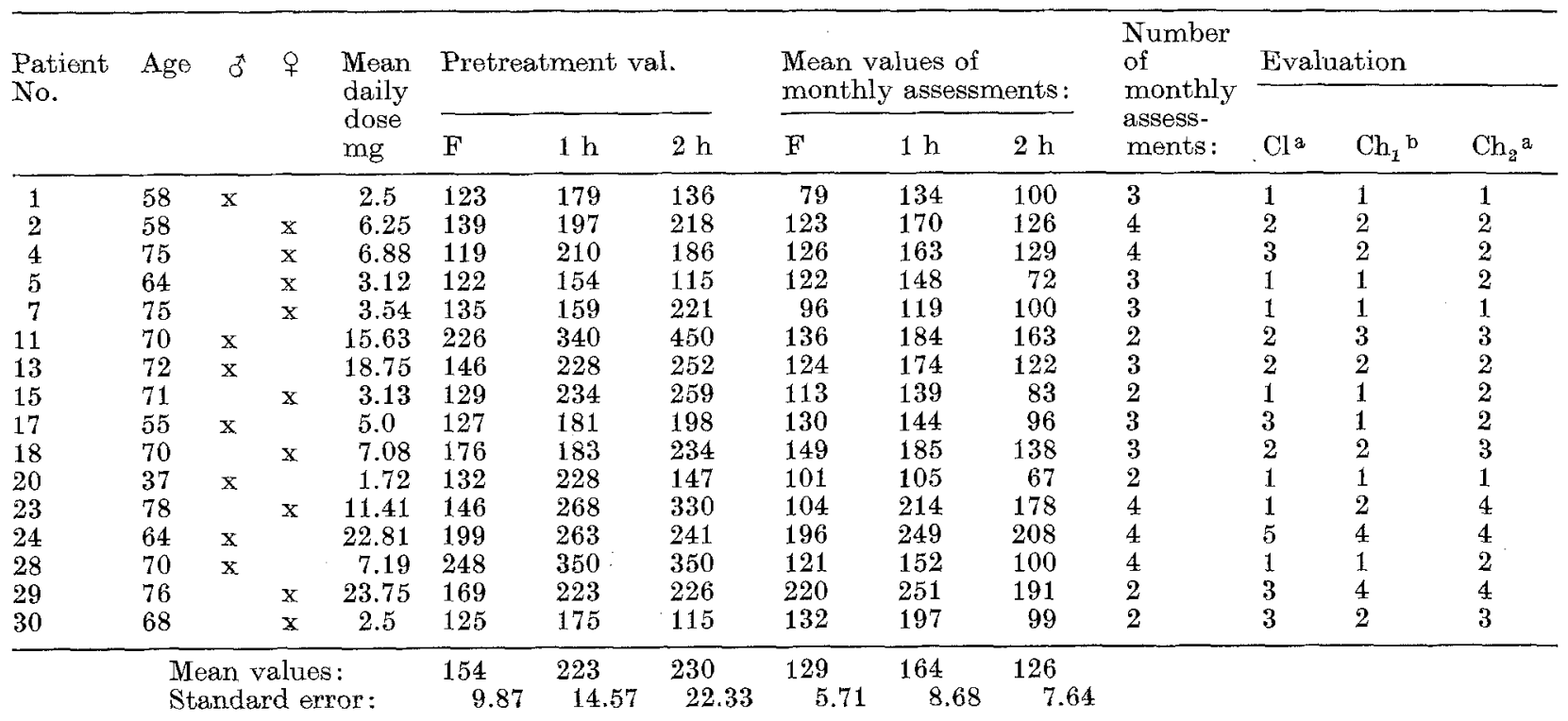

Key: a $1=$ excellent, $2=$ good, $3=$ fair, $4=$ poor, $5=$ negative.

b $1=$ excellent, $2=$ good, $3=$ fair, $4=$ negative.

Table 6. Tolbutamide

\begin{tabular}{|c|c|c|c|c|c|c|c|c|c|c|c|c|c|c|}
\hline \multirow[t]{2}{*}{$\begin{array}{l}\text { Patient } \\
\text { No.: }\end{array}$} & \multirow[t]{2}{*}{ Age } & \multirow[t]{2}{*}{$\mathrm{O}^{*}$} & \multirow[t]{2}{*}{ q } & \multirow{2}{*}{$\begin{array}{l}\text { Mean } \\
\text { daily } \\
\text { dose } \\
\text { mg }\end{array}$} & \multicolumn{3}{|c|}{ Pretreatment val. } & \multicolumn{3}{|c|}{$\begin{array}{l}\text { Mean values of monthly } \\
\text { assessments }\end{array}$} & \multirow{2}{*}{$\begin{array}{l}\text { Number } \\
\text { of } \\
\text { monthly } \\
\text { assess- } \\
\text { ments }\end{array}$} & \multicolumn{3}{|c|}{ Evaluation } \\
\hline & & & & & $\mathrm{F}$ & $1 \mathrm{~h}$ & $2 \mathrm{~h}$ & $\mathrm{~F}$ & $1 \mathrm{~h}$ & $2 \mathrm{~h}$ & & $\mathrm{Cl}^{\mathrm{a}}$ & $\mathrm{Ch}_{1}{ }^{\mathrm{b}}$ & $\mathrm{Ch}_{2}{ }^{\mathrm{a}}$ \\
\hline 6 & 71 & & $\mathrm{x}$ & 3167 & 230 & 350 & 350 & 94 & 166 & 106 & 3 & 2 & 1 & 2 \\
\hline 8 & 59 & $x$ & & 2750 & 138 & 256 & 278 & 166 & 191 & 170 & 3 & 4 & 3 & 4 \\
\hline 9 & 62 & & $x$ & 3000 & 194 & 208 & 275 & 122 & 183 & 164 & 1 & 2 & 2 & 3 \\
\hline 10 & $5 \overline{3}$ & $\mathrm{x}$ & & 2000 & 118 & 269 & 227 & 104 & 128 & 111 & 3 & 2 & 1 & 1 \\
\hline 12 & 68 & & $\mathrm{x}$ & 1833 & 191 & 370 & 274 & 131 & 192 & 143 & 3 & 2 & 2 & 3 \\
\hline 14 & 76 & & $x$ & 1750 & 158 & 278 & 335 & 156 & 222 & 234 & 2 & 5 & 4 & 4 \\
\hline 16 & 70 & $\mathrm{x}$ & & 500 & 126 & 199 & 122 & 68 & 110 & 76 & 3 & 1 & 1 & 1 \\
\hline 19 & 76 & & $\mathrm{x}$ & 1000 & 148 & 268 & 192 & 91 & 148 & 127 & 3 & 2 & 1 & 1 \\
\hline 21 & 75 & & $\mathrm{x}$ & 500 & 121 & 159 & 113 & 116 & 169 & 91 & 4 & $\overline{2}$ & 1 & 2 \\
\hline 22 & 69 & & $x$ & 1000 & 138 & 158 & 118 & 118 & 166 & 154 & 4 & 2 & 2 & 3 \\
\hline 25 & 61 & & $\mathrm{x}$ & 3000 & 181 & 248 & 284 & 142 & 172 & 210 & 4 & 4 & 3 & 4 \\
\hline \multirow[t]{2}{*}{27} & 69 & & $\mathrm{x}$ & 3333 & 203 & 246 & 206 & 244 & 329 & 308 & 3 & 5 & 4 & 5 \\
\hline & & & & or: & $\begin{array}{c}162 \\
10.59\end{array}$ & $\begin{array}{l}251 \\
18.88\end{array}$ & $\begin{array}{l}231 \\
23.76\end{array}$ & $\begin{array}{l}129 \\
7.87\end{array}$ & $\begin{array}{r}179 \\
9.85\end{array}$ & $\begin{array}{l}155 \\
11.45\end{array}$ & & & & \\
\hline
\end{tabular}

Key: ${ }^{a} 1=$ exellent, $2=$ good, $3=$ fair, $4=$ poor, $5=$ negative.

b $1=$ excellent, $2=$ good, $3=$ fair, $4=$ negative.

When the criteria "excellent", "good" and "fair" (Table 4) are combined, it can be stated that in $80-$ $90 \%$ of patients on glipizide and in $65-85 \%$ of patients on tolbutamide a reasonable degree of control could be achieved.

The results obtained with glipizide are comparable hour after load of patients on tolbutamide is somewhat higher than the corresponding value for glipizidepatients it can be stated that the blood-glucose lowering effect of glipizide is at least equal to that of tolbutamide.

After completion of a 12 month treatment course 
in 40 patients (20 glipizide, 20 tolbutamide) further results, including also the parameters of lipid metabolism and other laboratory values, will be reported.

\section{References}

1. Ambrogi, V., Bloch, K., Daturi, S., Griggi, P., Logemann, W., Parenti, M.A., Rabini, T., Tommasini, R.: New oral antidiabetic drugs part I. Drug. Res. 21, 200-204 (1971)

2. Ambrogi, V., Bloch, K., Cozzi, P., Daturi, S., Logemann, W., Parenti, M.A., Tommasini, R.: New oral antidiabetic drugs part II. Drug. Res. 21, 204-208 (1971)

3. Ambrogi, V., Bloch, K., Daturi, S., Griggi, P., Loge mann, W., Mandelli, V., Parenti, M.A., Rabini, T., Usardi, M. M., Tommasini, R.: Pharmacological study on a new oral antidiabetic: $\mathrm{N}-\{4-[\beta-(5-$ Methyl-pyrazine $2 \times$ carboxamido)-ethyl] - benzene-sulphonyl $\}-N^{3}$-cyclohexyl-urea or K 4024. Drug Res. 21, 208-215 (1971)

4. Marigo, S., del Nevo, G., Bixi, P.P., Sacchetti, G. Pharmacological methods for evaluating a new hypoglycaemic agent in humans: a Multistep Design. Drug Res. 21, 215-220 (1971)

5. Pedrazzi, F., Pisani Ceretti, A., Losi, S., Bommartini, F., Artini, D., Emanueli, A.: Evaluation in hospitalized subjects of a new hypoglycaemic sulphonylurea, glydiazinamide. Drug Res. 21, 220-225 (1971)

6. Ambrogi, V., Bloch, K., Daturi, S., Logemann, W., Parenti, M.A., Tommasini, R. New oral antidiabetic drugs part III. Drug Res. 22, 542-544 (1972)

7. Lentini, S., Bossini, A., Colombo Pirola, L.: A controlled clinical trial of a new oral hypoglycaemic agent, glipizide (K 4024). Drug Res. 22, 1169 - 1173 (1972)
8. D'Onofrio, F., Pempinello, R., Romis, L.: Clinical and metabolic observations with a new synthetic oral antidiabetic agent, glipizide. Drug Res. 22, 1879-1881 (1972)

9. Emanueli, A., Molari, E., Colombo Pirola, L., Caputo, G.: Glipizide, a new sulphonylurea in the treatment of diabetes mellitus. Drug Res. 22, 1881-1885 (1972)

10. Fedele, D., Tiengo, A., Riva, F., Muggeo, M., Emanueli, A., Crepaldi, G.: Modifications of glycaemia and insulinaemia in diabetes treated with glipizide $(\mathrm{K}$ 4024), a new sulphonylurea. Drug Res; 22, 1885- 1888 (1972)

11. Vailati, G., Pagani, G., Montini, M., Caputo, G., Sacchetti, G.: Effect of glipizide on a double-meal test in diabetic patients. Drug Res. 22, $1888-1889$ (1972)

12. Schliack, V., Mohnicke, H., Rost, H., Honigmann, G., Jahnke, K., Schilling, W., Gutsche, H., Blumenbach, H., Walker, J.B., Kerridge, D., Keen, H., Jarrett, R.J., Eschwege, E., Hoet, J.J., Syllaba, J., Teuscher, A., Glasunov, T., Jaksic, Z., Skrabalo, Z., Andreev, D.: Report of the European Epidemiology Study Group Diabetologia 6, 646 (1970)

13. Teuscher, A., Richterich, R.: Neue schweizerische Richtlinien zur Diagnose des Diabetes mellitus. Schweiz. med. Wschr. 101, 345-352, 390-398 (1971)

14. Frehner, H.U.: Diabetes-Fibel, p. 129. Stuttgart: Georg Thieme 1972

15. Robbers, H.: Praktische Diabetologie, p. 123. München: Dr. Edmund Banaschewski 1969

16. Schöffling, K.: Überwachung und Einstellung des Diabetikers. M'Kurse ärztl. Fortb. 8, 319-327 (1970)

\section{Dr. K. Fuchs}

Internal Specialist

A-6200 Jenbach

Austria 